\title{
Diversity of the genus Genkalia (Bacillariophyta) in boreal and mountain lakes - taxonomy, distribution and ecology
}

\author{
Agata Z. Wojtal ${ }^{1 *}$, Nadja Ognjanova-Rumenova ${ }^{2}$, Carlos E. Wetzel ${ }^{3}$, Friedel \\ Hinz $^{4}$, Jolanta PiąteK ${ }^{5}$, Tatjana KaPetanovic ${ }^{6}$, Luc Ector ${ }^{3} \&$ Krisztina BuczKó $^{7}$
}

\author{
${ }^{1}$ Institute of Nature Conservation, Polish Academy of Sciences, A. Mickiewicza 33, 31-120 Kraków, Poland; \\ *Corresponding authore-mail: wojtal@iop.krakow.pl \\ ${ }^{2}$ Department of Paleontology, Stratigraphy and Sedimentology, Geological Institute, Bulgarian Academy of \\ Sciences, Acad. G. Bonchev-Street 24, 1113 Sofia, Bulgaria \\ ${ }^{3}$ Department of Environment and Agro-biotechnologies (EVA), Public Research Centre - Gabriel Lippmann, \\ Rue du Brill 41, 4422 Belvaux, Luxembourg \\ ${ }^{4}$ Alfred Wegener Institute for Polar and Marine Research, Am Handelshafen 12, 27570 Bremerhaven, \\ Germany \\ ${ }^{5}$ Department of Phycology, W. Szafer Institute of Botany, Polish Academy of Sciences, Lubicz 46, 31-512 \\ Kraków, Poland \\ ${ }^{6}$ Environmental Fund of the Federation of Bosnia and Herzegovina, Hamdije Čemerlica 39A, BiH-71000 \\ Sarajevo, Bosnia and Herzegovina \\ ${ }^{7}$ Department of Botany, Hungarian Natural History Museum, Könyves Kálmán krt. 40, 1476 Budapest, \\ Hungary
}

\begin{abstract}
Genkalia digitulus (Hustedt) LANGE-Bert. et Kulikovskiy (三Navicula digitulus Hustedt) is recorded from several lakes in the northern Europe and from high altitude lakes all over Europe. Wide distribution and characteristic autecology of this species allow its use as a bioindicator of $\mathrm{pH}$ changes and reliable marker of environmental reconstruction. A comparison of specimens found in lakes from the Carpathian and Balkan Mountains with the type material of Genkalia digitulus (Hustedt) LANGE-Bert. et Kulikovskiy resulted in description of a new species - G. boreoalpina Wojtal, C.E. Wetzel, Ector, OgnJanova-Rumenova et Buczkó. Genkalia boreoalpina is characterised by valve outline, size and parallel striae throughout most of the valve. The separation was based on light and scanning electron microscopy. Genkalia boreoalpina was the most common diatom of the genus from high mountain lakes of slightly acidic waters with a very low mineral content. The third species, Navicula subprocera HustedT, was found in the Lake Câlcescu (Parâng Mountains) in alkaline waters and in a mountain fen in Herzegovina. The nomenclatorial combination to Genkalia was made for this species. Previously published data suggest there is a much larger diversity of species in the genus Genkalia and the cosmopolitan distribution of this group is mostly presented at the genus level.
\end{abstract}

Key words: Balkans, Carpathians, morphological variability, Navicula, oligotrophy, pH change, type material

\section{INTRODUCTION}

The genus Genkalia Kulikovskiy, Lange-Bert. et MetZeltin was recently described from the lake Baikal (KuLIKOVSKIY et al. 2012). It presently comprises eleven species, most of them of unknown distribution and observed only at their type localities. This genus is characterized by a naviculoid outline and shares several characteristics with the genera Adlafia LANGEBert. and Boreozonacola Lange-Bert., KUlikovskiY et Witкowski. Among the taxa actually placed in the genus, Navicula digitulus Hustedt (1943: 162) [三 Genkalia digitulus (Hustedt) Lange-Bert. et KuLIKovskiY in KuLIKovsKIY et al. (2012: 142)] is a common taxon in high latitude and high altitude lakes of the Holarctic region (SABATER \& ROCA 1992; BigLER \& Hall 2002, 2003; Catalan et al. 2009; Krstić et al. 2012). According to the literature, G. digitulus (as Navicula digitulus) is a common species, abundant in lakes of the northern Europe (Bigler \& HALL 2002, 2003; LARSEN et al. 2006) though it is also known from several mountain lakes (KAWECKA \& GaLAS 2003; Štefková 2006; Buczkó et al. 2009, 2013a; OgnJANOva-Rumenova et al. 2009, 2011; GąSIOROWSKI \& SiENKIEwICZ 2010). This diatom is widespread in boreoalpine climate and especially abundant in cold, oligotrophic and weakly acidic waters, poor in electrolytes (BIGLER et al. 2000; FALLu et al. 2000; RosÉN et al. 2000; Bigler \& Hall 2002; Larsen et al. 2006). Despite importance and commonness of $G$. digitulus 
in dilute waters problems with its identification have been found (e.g. MarciniaK \& CieŚla 1983; FAllu et al. 2000). Moreover, the European Diatom Database (EDDI) (JugGins 2001) which encompasses a large dataset for G. digitulus (as Navicula digitulus) has only one vouchered (illustrated) specimen that differs from N. digitulus sensu Hustedt 1943.

Genkalia digitulus was described as Navicula digitulus by HUSTEDT (1943: 162) from a high mountain lake - Schwarzsee near Davos in Switzerland. The species was found in only one sample; though another locality (spring near Benneckenstein in Harz, Germany) was also mentioned by Hustedt (1943). The species diagnosis is supported by five drawings showing finely striated valves of linear-lanceolate outline with protracted, rounded apices and round central area of different size. A similar species - Navicula subprocera Hustedt (1945: 920, plate 41, fig. 1) - found in the Buna spring (Bosnia and Herzegovina) was established two years later. The original drawing of $N$. subprocera supports the description showing lanceolate valve with bluntly rounded ends and a large, rhombic central area (Hustedt 1945, plate 41, fig. 1). In 1986 Krammer \& LANGE BERTALOT extended the morphological range of Navicula digitulus (1986: 204, plate 77, figs 19-24 \& “evtl. 25-28") including N. subprocera (plate 77, fig. 25) and even the specimens with linear valves having 28-40 striae in $10 \mu \mathrm{m}$. Then the detailed study of diatom flora of oligotrophic Lake Julma Ölkky in Finland resulted in description of Naviculadicta digituloides LANGE-Bert. in LANGE-BERTALOT \& Metzeltin (1996: 83, plate 109, figs 8-9, plate 115, fig. 4). Among characteristics which distinguish Naviculadicta digituloides from Navicula digitulus there were stated - more linear than lanceolate outline, obtusely rounded ends, large and rhombic central area. According to Lange-Bertalot (in LANGe-Bertalot \& MetZeltin 1996) both species can co-occur in oligodystrophic waters. They were included to the genus Genkalia Kulikovskiy, Lange-Bert. et Metzeltin (KulikovskiY et al. 2012: 134) along with nine newly described species from Lake Baikal.

The aim of this study was to reexamine the morphology of Navicula digitulus from the HUSTEDT type material and make comparisons with Genkalia specimens from Carpathian and Balkan localities from eastern and southern Europe.

\section{Materials and Methods}

The following material was examined:

1. Type material of Navicula digitulus HUSTEDT 1943: material number BRM E1319 bottom of Schwarzsee, Davos 126 , Switzerland, 24 ${ }^{\text {th }}$ July 1930 , located over timberline (2388 $\mathrm{m}$ a.s.1.).

2. Type material of Navicula subprocera Hustedt 1945 (page 920): material number BRM E4191, from a puddle at the source of the river Buna at Blagaj, about $12 \mathrm{~km}$ from Mostar (Herzegovina), collected on $2^{\text {nd }}$ May 1909.

3. Mountain fen in Bijambare, Dinaric Mts near Sarajevo (Bosnia and Herzegovina) collected in May and October 2007 and May 2008 from the marginal part of the fen.

4. Nine lakes, situated in three different cirques in Rila Mountains (Table 1). Sediment cores from the deepest part of the nine lakes were retrieved in July and August 2000; the samples were considered older than c. 1800 AD. Epilithon from the Lake Bubreka was additionally collected in $26^{\text {th }}$ September 2013.

5. Lake Avrig (Făgăraș Mountains) on $7^{\text {th }}$ August 2012, Lake Calcescu (Parâng Mountains) on $14^{\text {th }}$ August 2012, Lake Caprelor (Retezat Mountains) in July 2013, all collected by Csilla Kövér and core samples from Lake Lia, Lake Brazi and Lake Gales (Retezat Mountains), drilled in 2007 and 2008, collected by Mihály Braun and Enikő Magyari.

6. Near-shore sediments from Lake Zadni Staw Gąsienicowy. The recent samples were collected on $23^{\text {rd }}$ September 2005 by Jolanta Piątek.

All studied habitats were characterized by slightly acidic to circumneutral water of very low water conductivity (12-36 $\left.\mu \mathrm{S} . \mathrm{cm}^{-1}\right)$. The only exception in terms of ion concentration was the fen in Bijambare protected area (KAPETANOvić et al. 2011). Higher $\mathrm{pH}$ values were recorded only in the Lake Okoto, Lake Avrig and Lake Calcescu (Table 1). Schwarzsee near Davos (Switzerland) is a small lake in the western Swiss Alps. Spring Buna (Bosnia and Herzegovina) is a cold-water, karstic spring with a large discharge, south-east from Mostar. The mountain fen in the Bijambare protected area (Bosnia and Herzegovina) is of postglacial origin and the climate of this region is moderately continental, with strong impacts of mountain climate. All the lakes of Rila Mountains (Bulgaria) are located above the timberline and are of glacial origin. Glacial lakes in Retezat Mountains (Southern Carpathians) were formed mainly during the Late Glacial (Buczkó et al. 2009). The Lake Zadni Staw Gąsienicowy remains frozen for most of the year.

The samples were digested using concentrated $\mathrm{H}_{2} \mathrm{O}_{2}$ and heating. Air-dried material was mounted in Naphrax ${ }^{\mathbb{B}}$. The diatoms were identified with a Nikon Eclipse 80i light microscope with phase contrast (DIC), Leica DM LB2 with 100 HCX PLAN APO objective, Leica ${ }^{\circledR}$ DMRX brightfield microscope with $100 \times$ oil immersion objective. Light micrographs were taken with a Nikon DS-Fi, VSI-3. $\mathrm{OM}(\mathrm{H}) \mathrm{a}$ Leica ${ }^{\circledR}$ and DC500 cameras, respectively. The cleaned samples were sputter-coated with gold-palladium or palladium and a Hitachi S-26000N scanning electron microscope (Figs 36, 93-96, 116, 117) and an ultra-highresolution analytical field emission (FE) scanning electron microscope Hitachi SU-70 (Hitachi High-Technologies, Europe, GmbH) (Figs 37-48, 97-109) were used for the analysis. Micrographs were digitally manipulated and plates containing light and scanning electron microscopy images were created using CorelDraw X $5^{\circledR}$. 


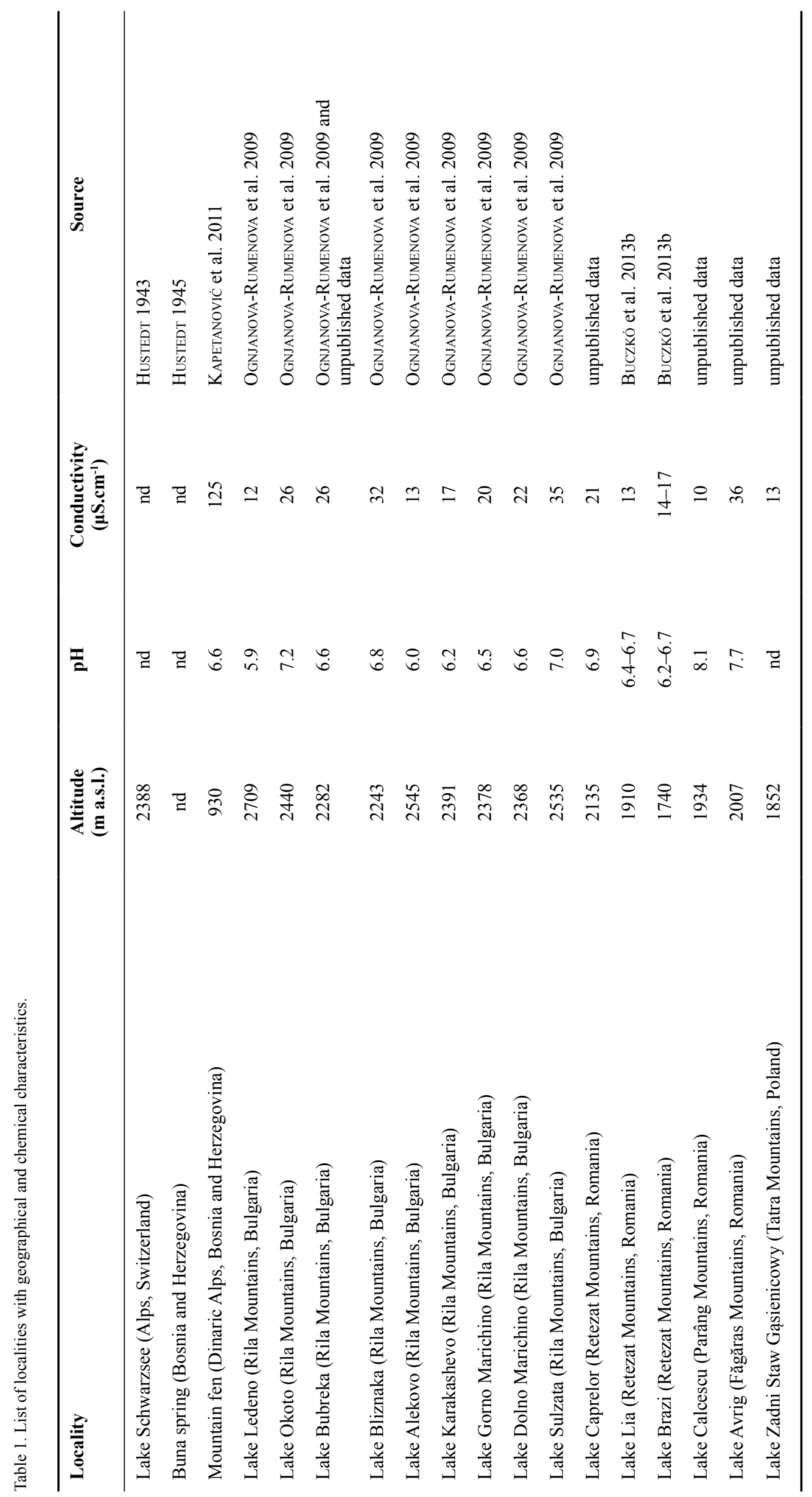




\section{RESULTS}

Three species of the genus Genkalia were found in lake habitats of the Carpathian and Balkan mountains. The most common was here described as Genkalia boreoalpina sp. nov. The highest abundance of $G$. digitulus was observed in weakly acidic lakes. The third species, G. subprocera (= Navicula subprocera) was found in the Lake Calcescu and in a mountain fen in the Bijambare protected area, where sparse individuals co-occurred with less abundant and smaller specimens of $G$. digitulus.

Genkalia digitulus (HuStedt) LANGE-BERT. et KulikovskiY in KulikovskiY et al. (2012) [(Figs 1-35, LM; 36-48 (SEM)]

Basionym: Navicula digitulus Hustedt (1943: 162, figs 26-30)

三 Naviculadicta digitulus (HUSTEDT) LANGE-BERT. in LANGEBertalot \& Metzeltin 1996: 84, figs 109: 30-33; 115: 3. Type: Switzerland, Schwarzsee; sample E1319, 24 $4^{\text {th }}$ July 1930.

Description of type material (Figs 2-14, 37-48): Valves are lanceolate with gradually tapered and rounded ends or are protracted into short subrostrate apices. They are 8.0-20.0 $\mu \mathrm{m}$ long $(\mathrm{N}=22)$ and 3.0-5.0 $\mu \mathrm{m}$ wide $(\mathrm{N}=22)$. Axial area is narrow, linear. Central area is variable in size, from very small up to moderate corresponding with Hustedt drawings (here Fig. 1a-e). Striae are uniseriate, slightly radiate in the mid-valve (27-34 in $10 \mu \mathrm{m}$ ) becoming parallel towards the apices (32-40 in $10 \mu \mathrm{m})$. Areolae are discernible in LM. Length and width ratio varies between 2.0 and 4.5.

In SEM terminal fissures are externally unilaterally curved to the secondary side. Proximal raphe terminals are not expanded and very slightly bent to the primary side. Raphe is straight, or weakly sigmoid, lying in the middle of axial area. Striae are composed of round areolae, running continuously over valve face across the margin and down onto the mantle. A Voigt discordance is present. Internally raphe branches are straight with abruptly bent to the primary side proximal terminals. Distal terminals are in small, simple helictoglossa. Central nodule is elevated; striae are composed of transapically elongated or round areolae.

Description of material from lakes Lia, Gales, Calcescu, Avril, Caprelor and Brazi (Figs 15-36): Valves are lanceolate or linear-lanceolate with short protracted apices. They are 9.0-17.0 $\mu \mathrm{m}$ long $(\mathrm{N}=32)$ and 3.5-5.5 $\mu \mathrm{m}$ wide $(\mathrm{N}=29)$. Axial area is narrow and linear. The central area is small. Striae are slightly radiate in the mid-valve becoming parallel towards apices. Areolae are discernible in LM. Foramina are closed by hymenes on the outside and can be observed in SEM when valves are not corroded (Fig. 36).
Ecology and Distribution: Genkalia digitulus was found in recent and fossil samples from Dinaric Mountains and Carpathians. The majority of habitats were of very low mineral content and slightly acidic water (Table 1). The only exceptions were: margins of the lakes Calcescu and Avril, sediment samples of Lake Okoto (the deepest lake), Lake Sulzata (the only lake without inflow) and the mountain fen in Bijambare area (Table 1). Wide distribution and conspicuous morphology suggest a high indicative value of this diatom, especially for $\mathrm{pH}$ changes reconstruction and ionic concentration.

Remarks: Analysis of the original description and type material suggests that the HuSTEDT' concept of Genkalia digitulus (as Navicula digitulus) was based on morphologically heterogeneous assemblage of diatoms. The original HustedT' description (1943) is supported by five drawings showing finely striated valves of linear-lanceolate outline with rounded apices, round central area of different size and narrow, linear axial area (Fig. 1a-e). The description of Navicula digitulus repeated by HuSTEDT in 1961-1966 is illustrated by six drawings of which five specimens have large and round central area and rounded ends, although in the diagnosis (HusteDT 1943) valves with broadly rounded or sometimes very weakly protracted ends and small central area are stated. The specimens selected by SIMONSEN (1987) originate from the slide originally labeled by HUSTEDT, but they are not the same as those used by HusteDT for line-drawings (the references to iconotypes are lacking). Four lanceolate valves/frustules of Navicula digitulus (SIMONSEN 1987, plate 470, figs 4-9) cover the morphological range indicated by Hustedt (1943). First specimen (SiMONSEN 1987, p. 311, plate 470, figs 4, 5) has bluntly rounded ends and a relatively large central area. Three other specimens have a small central area and short protracted ends.

The specimens with short protracted apices and small central area represent a morphological range in terms of length and width (Figs 3-10, 13, 14, 18-24, $29,30,34,35)$. The cells with gradually tapered valves co-occurred with them in the type material of Navicula digitulus and in populations from lakes in the Retezat Mountains (Figs 2, 11, 12, 15-17, 25, 26, 28-33). Comparison of both morphologies in SEM has not shown distinct differences between these valve forms. Only one valve, the smallest specimen found in the type material has an elliptic outline with a very small central area and very weak radial striae in the middle portion of valve. Areolae on the valve face are smaller and transapically elongated along the axial area (Fig. 41). The specimens with and without short protracted ends were most abundant in the Retezat Mountains. Among them some specimens found in the Lake Lia show almost parallel valve margins in the middle portion of valve (Figs 19-21). Each stria on the mantle around the 


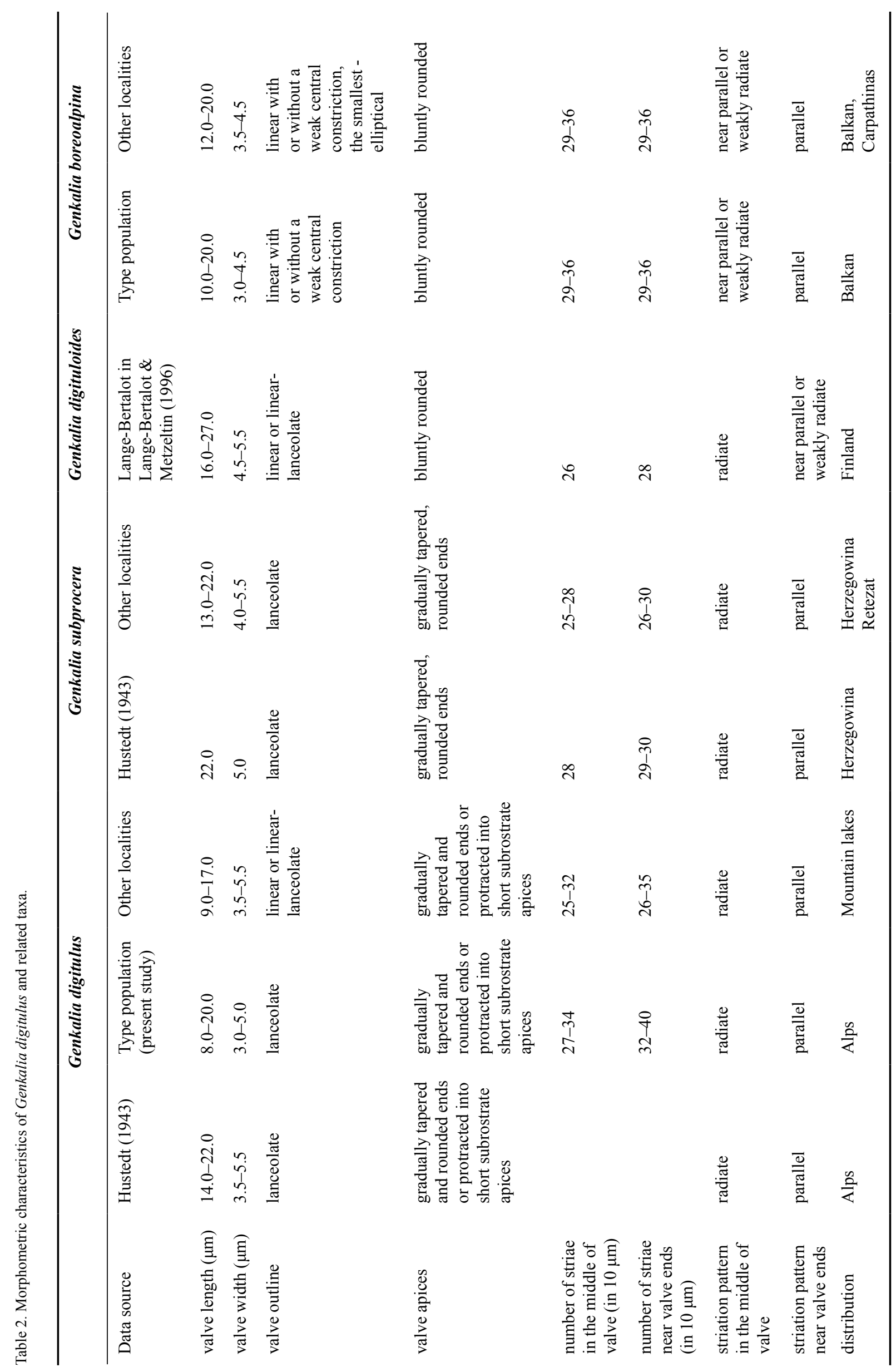




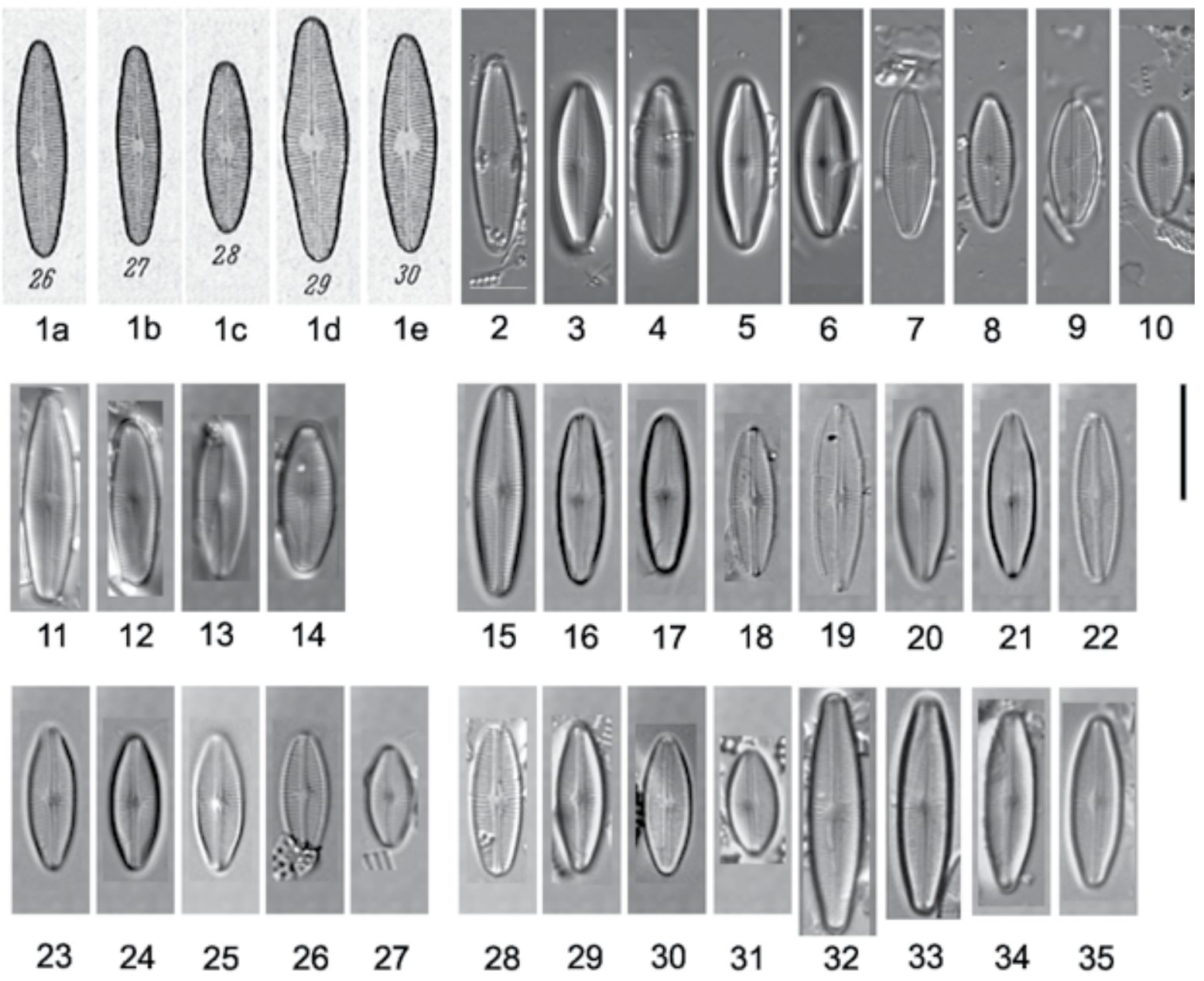

Figs 1-35. Genkalia digitulus (HuSTEDT) LANGE-BerT. et KuliKovskiY: (1a-1e) original drawings of Navicula digitulus after HUSTEDT 1943; (2-14) Genkalia digitulus from the type material - Schwarzsee, sample E1319, LM; (15-35) G. digitulus from other localities: Carpathians, Balkans, LM. Scale bar $10 \mu \mathrm{m}$.

apex is composed of only one elongated areola.

Genkalia boreoalpina Wojtal, C.E. Wetzel, Ector, Ognjanova-Rumenova et Buczkó sp. nov. (Figs 49109)

Description: Valves are linear with or without a weak central constriction, 10-20 $\mu \mathrm{m}$ long $(\mathrm{N}=66)$ and 3.0 $4.5 \mu \mathrm{m}$ wide $(\mathrm{N}=56)$, with bluntly rounded apices. The smallest valves have linear-elliptic outline. Axial area is narrow, linear. Central area is distinct and round or rhombic. Raphe branches are filiform and straight. Striae are uniseriate, composed of fine but distinct areolae, parallel throughout most of the valve only about the central area - parallel or slightly radiate.

SEM: Externally the valve face is flat. The raphe is slightly sigmoid and lateral, lying closer to secondary side. Distal raphe terminals are turned to the secondary side. Proximal raphe ends are simple, straight or slightly bent to the primary side. Axial area is narrow and linear. The shape of central area is usually rounded, though it varies according to the number of short striae near the central area. Sometimes, one short stria is unilaterally intercalated. Striae are parallel, only near the central area they can be slightly radiate and are more distant from each other than in the other part of the valve. A Voigt discordance is present (Figs 93, 94, 96). Striae are uniseriate, $29-36$ in $10 \mu \mathrm{m}$. Areolae are round or transapically elongated, especially on the valve mantle. The striae run continuously over the valve surface, across the margin and down onto the valve mantle. At the base of the mantle at each apex each stria is composed of two areolae. The narrow girdle of each theca consists of copulae. Internally proximal raphe ends are abruptly bent towards primary side. Distal raphe terminals are in simple, small helictoglossa. Areolae are round or transapically elongated, occluded. Central nodule is slightly elevated.

Type locality: Switzerland, Schwarzsee

Holotype (designated here): Fig. 49, Schwarzsee Friedrich Hustedt Collection Alfred Wegener Institut, Bremerhaven, Germany, access number - ZU9/74.

Isotype: Institute of Nature Conservation, Kraków, Poland, access number - DW 14.

Etymology: The species epithet is related to the 

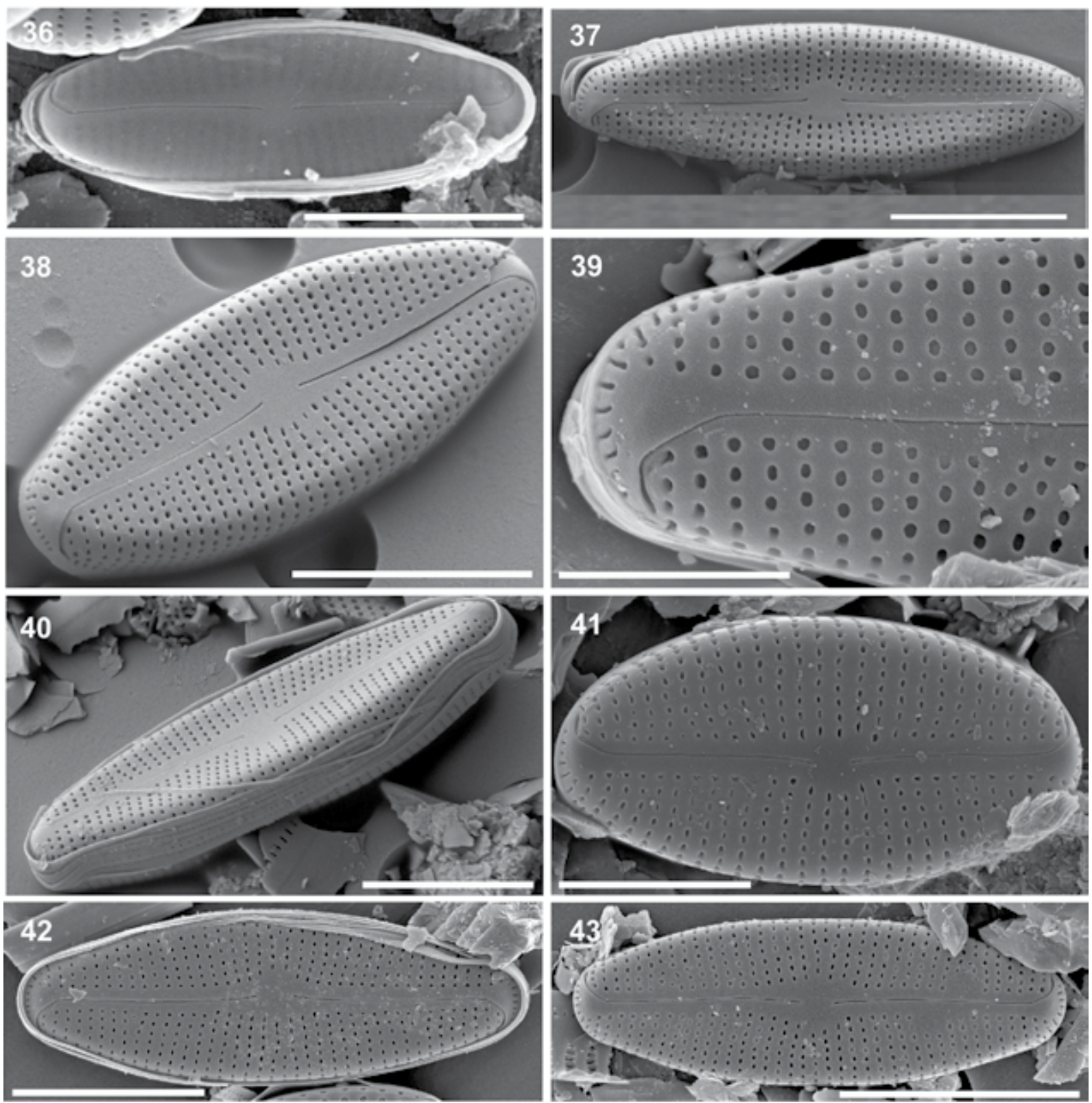

Figs 36-43. Genkalia digitulus (Hustedt) LAnge-Bert. et Kulikovskiy: (36) from Carpathians, external view of not corroded valve; (37-43) G. digitulus from the type material - Schwarzsee, sample E1319. External view of valves, SEM. Scale bars $5 \mu \mathrm{m}(36-38,40,42,43), 2 \mu \mathrm{m}$ (39), $3 \mu \mathrm{m}(41)$.

distribution of this taxon in the northern hemisphere and mountain areas.

Ecology and Distribution: Genkalia boreoalpina was found in several recent and fossil samples from lakes in Rila Mountains (Balkans), Făgăras Mountains, Retezat Mountains (Southern Carpathians), Tatra Mountains (Western Carpathians) and in the type material of Navicula digitulus from the Alps. A stable suite including weakly acidic to alkaline water of very low mineral content, wide distribution (in the Holarctic region), and conspicuous valve morphology suggest that this taxon has a high indicative value for environmental assessments.
Remarks: Genkalia boreoalpina is similar to $G$. digitulus in size, raphe morphology and presence of uniseriate striae. However, it differs in outline, morphologies of transapical striae, ornamentation of the mantle around apices, the position of central raphe fissure, and central area size. The most similar species G. digituloides (LANGe-Bert.) Lange-Bert. et KuLIKovskiY in KulikovskiY et al. (2012) is described from Julma Ölkky Lake in Finland (Lange-BERTALOT \& Metzeltin 1996). Genkalia digituloides has curving striae in the middle part of the valve whereas the transapical striae of $G$. boreoalpina are straight. The larger size, distinct radial striae through a large part of the valve suggest the separation of G. boreoalpina 

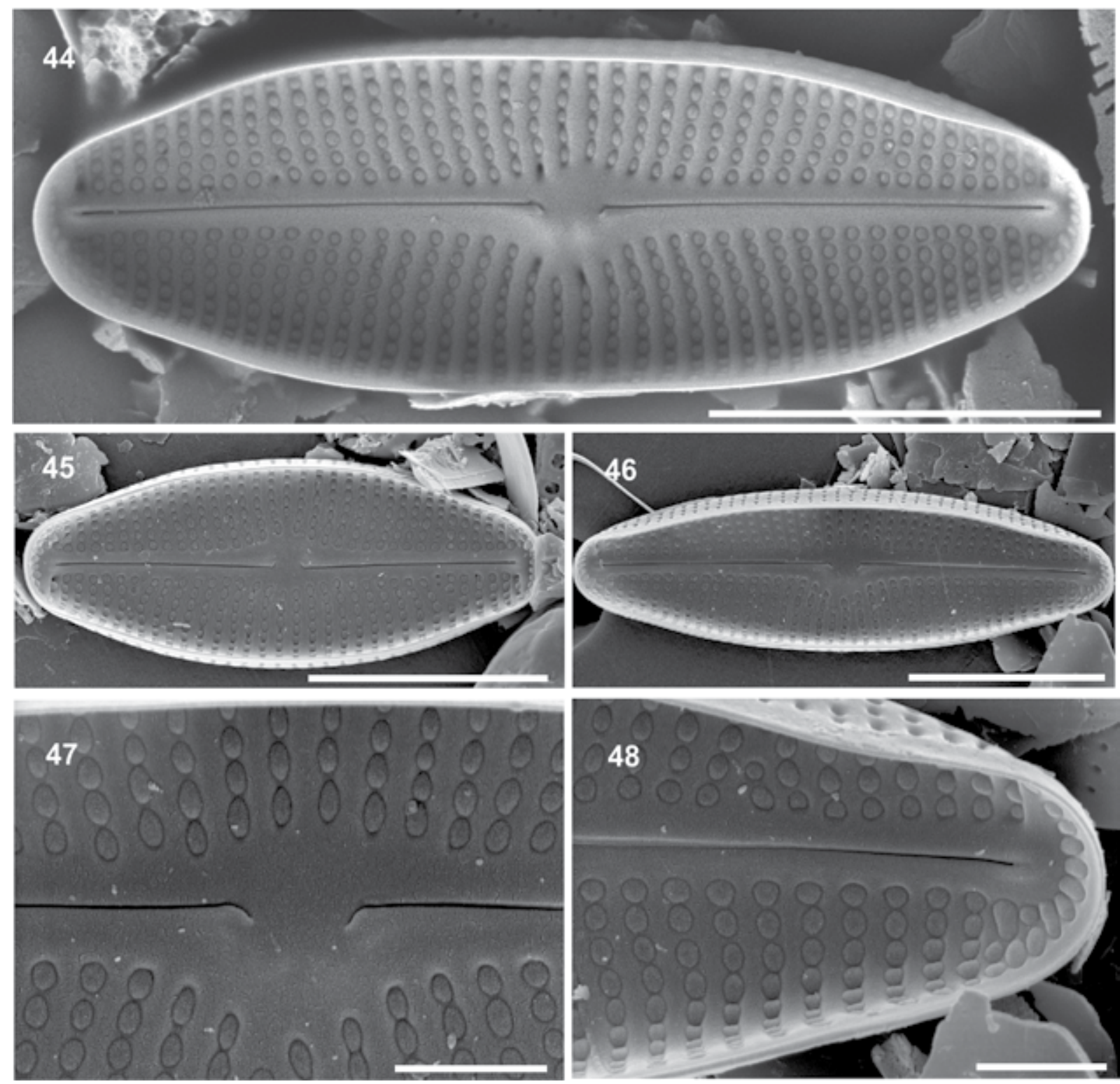

Figs 44-48. Genkalia digitulus from the type material - Schwarzsee, sample E1319. Internal view of valve, SEM. Scale bars $5 \mu$ m (44-46), 1 $\mu \mathrm{m}(47,48)$.

from $G$. digituloides, though their conspecifity cannot be definitely excluded. Navicula lange-bertalotii E. REICHARDT (1985: 176) [= Fallacia lange-bertalotii (E. REICHARDT) E. REICHARDT] is another diatom similar in LM. Navicula lange-bertalotii and Genkalia boreoalpina are similar in outline, dimensions, round central area, striae organization but differ in genus specific features, e.g. F. lange-bertalotii has multiseriate striae. Some specimens found in the Rila lakes (Figs 91, 92) are slender and have a linear-lanceolate outline (13.0-15.0 $\mu \mathrm{m}$ long and 3.5-3.6 $\mu \mathrm{m}$ wide).

After examining previously published illustrations, Genkalia boreoalpina appears to have a broad northern hemisphere distribution. Beginning from the type material of Navicula digitulus (KRAMMER \& Lange-Bertalot 1986, fig. 77: 20 - "Typenpräp. Coll. HustedT N2/69" and from other, unknown locality (Krammer \& LANGe-Bertalot 1986, fig. 77: 23), Canada (FAllu et al. 2000, plate 14, fig. 19 as Navicula digitulus and as Navicula sp. 37 Quebec), Siberia (Genkal \& Kharitonov 2010, plate 1, figs 1-5, 7, 8 as Naviculadicta digituloides) and a small alpine lake (GüTtINGER 1999).

Genkalia subprocera (HuSTEDT) WoJTAL, Ector, C.E. Wetzel, Ognjanova-Rumenova et Buczkó comb. nov. (Figs 110-117)

Basionym: Navicula subprocera HustedT (Archiv für Hydrobiologie 1945: 920, plate XLI, fig. 1).

Type: Herzegovina, Buna spring; sample E 4191, $2^{\text {nd }}$ May 1909; holotype slide N17/47.

The description of Genkalia subprocera is based on the HustedT drawing (1945, fig. 1): the valve is lanceolate 


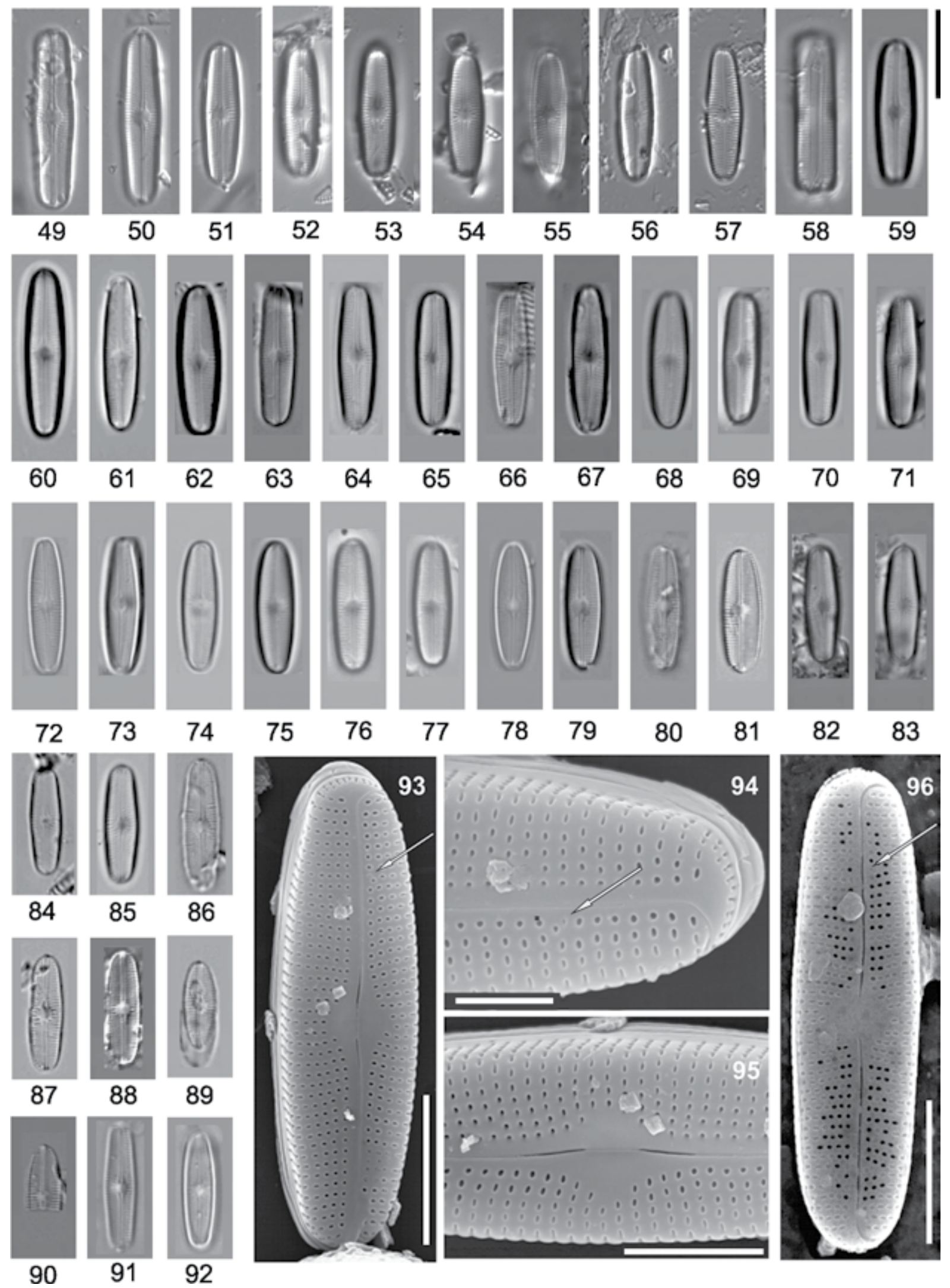

Figs 49-96. Genkalia boreoalpina Wojtal, C.E. Wetzel, Ector, Ognjanova-Rumenova et Buczkó sp. nov.: (49-58) type material of G. boreoalpina - Schwarzsee, sample E1319, (51) holotype of G. boreoalpina; (59-96) G. boreoalpina from Rila Mountains lakes, Retezat Mountains and Tatra Mountains, LM; external view of valve from Ledeno lake (93-95) and lateglacial part of Lake Brazi (96), Voigt discordance arrowed, SEM. Scale bars $10 \mu \mathrm{m}$ (49-92); $5 \mu \mathrm{m}$ (93, 96), $2 \mu \mathrm{m}$ (94), $3 \mu \mathrm{m}$ (95). 

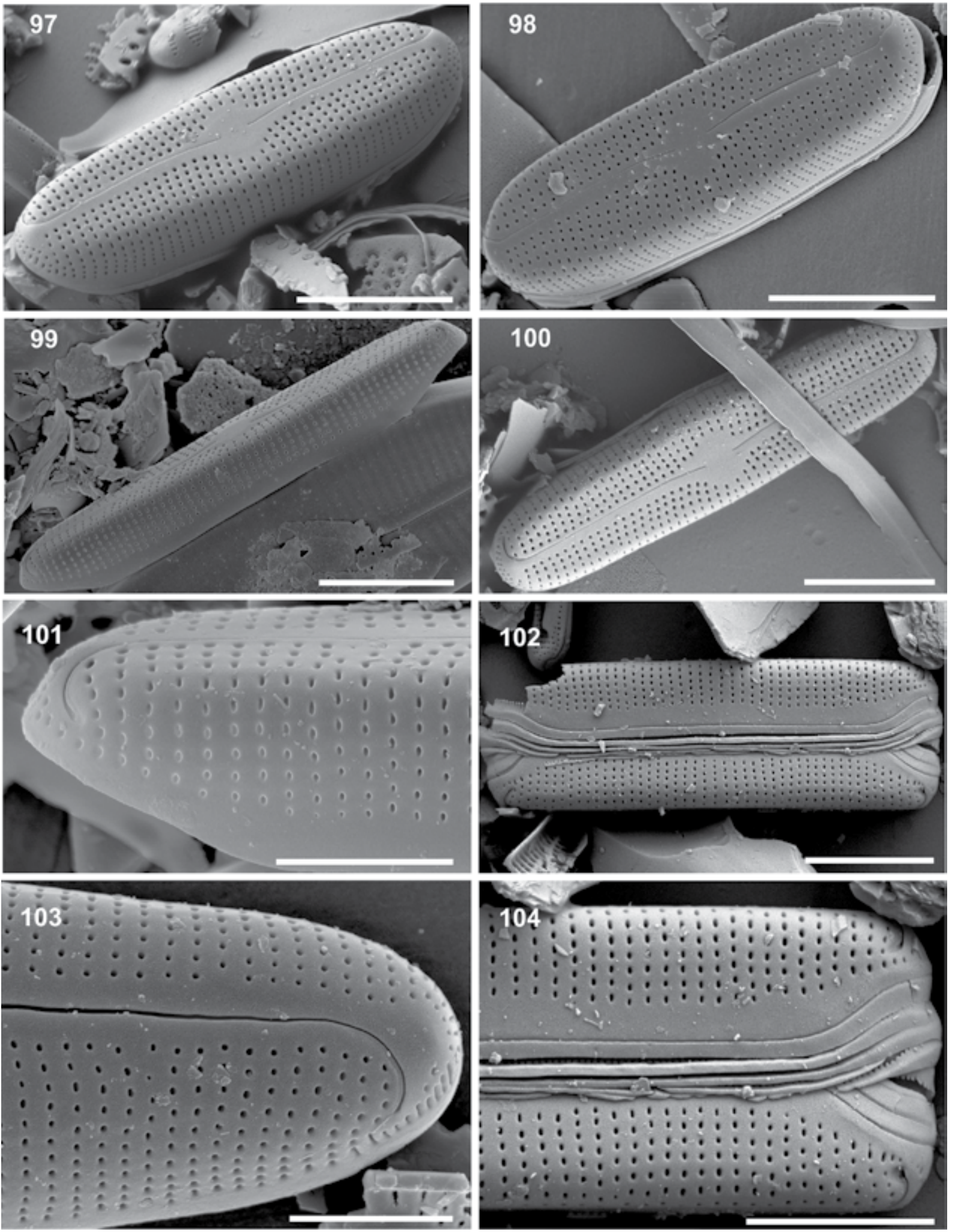

Figs 97-104. Genkalia boreoalpina Wojtal, C.E. Wetzel, Ector, Ognjanova-Rumenova et Buczkó sp. nov., external view of valve, type material, Schwarzsee, SEM. Scale bars $5 \mu \mathrm{m}(97-100,102), 2 \mu \mathrm{m}(101,103), 4 \mu \mathrm{m}(104)$. 

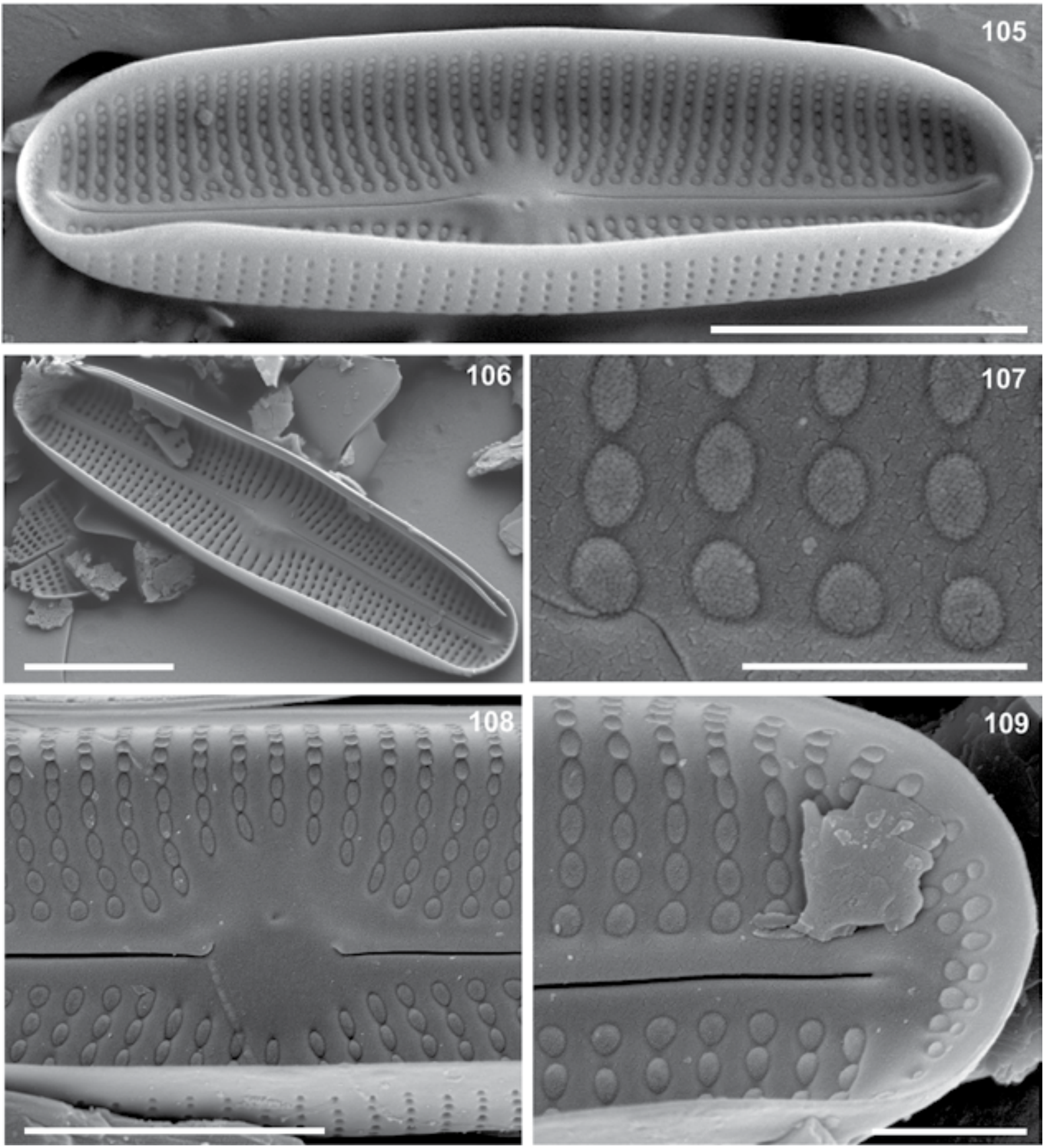

Figs 105-109. Genkalia boreoalpina Wojtal, C.E. Wetzel, Ector, Ognjanova-Rumenova et Buczkó sp. nov., internal view of valve, type material, Schwarzsee, SEM. Scale bars $5 \mu \mathrm{m}(105,106), 1 \mu \mathrm{m}(107,109), 3 \mu \mathrm{m}(108)$.

with gradually tapering, rounded ends; $22 \mu \mathrm{m}$ long and $5 \mu \mathrm{m}$ wide. Axial area is linear; central area is large and rhombic, sometimes it is asymmetric but does not reach the valve margins. Striae are uniseriate, radial in the middle position of the valve becoming nearparallel towards the apices, $28-30$ in $10 \mu \mathrm{m}$. Striae are more distant from each other around the central area.

\section{Description of material from Lake Câlcescu and} Bijambare fen (Figs 112-117): Valves are lanceolate with gradually tapered, rounded apices, 13.0-22.0 $\mu \mathrm{m}$ long $(\mathrm{N}=8)$ and $4.0-5.5 \mu \mathrm{m}$ wide $(\mathrm{N}=8)$. Raphe is filiform but distinct with small central pores. Axial area is linear and narrow. Central area is large, rhombic, and sometimes asymmetric but does not reach the valve margin. Striae are radial in the middle of the valve becoming parallel towards apices, $25-30$ in $10 \mu \mathrm{m}$. In the middle portion of the valve the striae are more distant from each other than in the other.

Remarks: The original diagnosis was illustrated only by one specimen. In the diagnosis HustedT stated that Genkalia subprocera (as Navicula subprocera) was very rare in the type material and probably only 

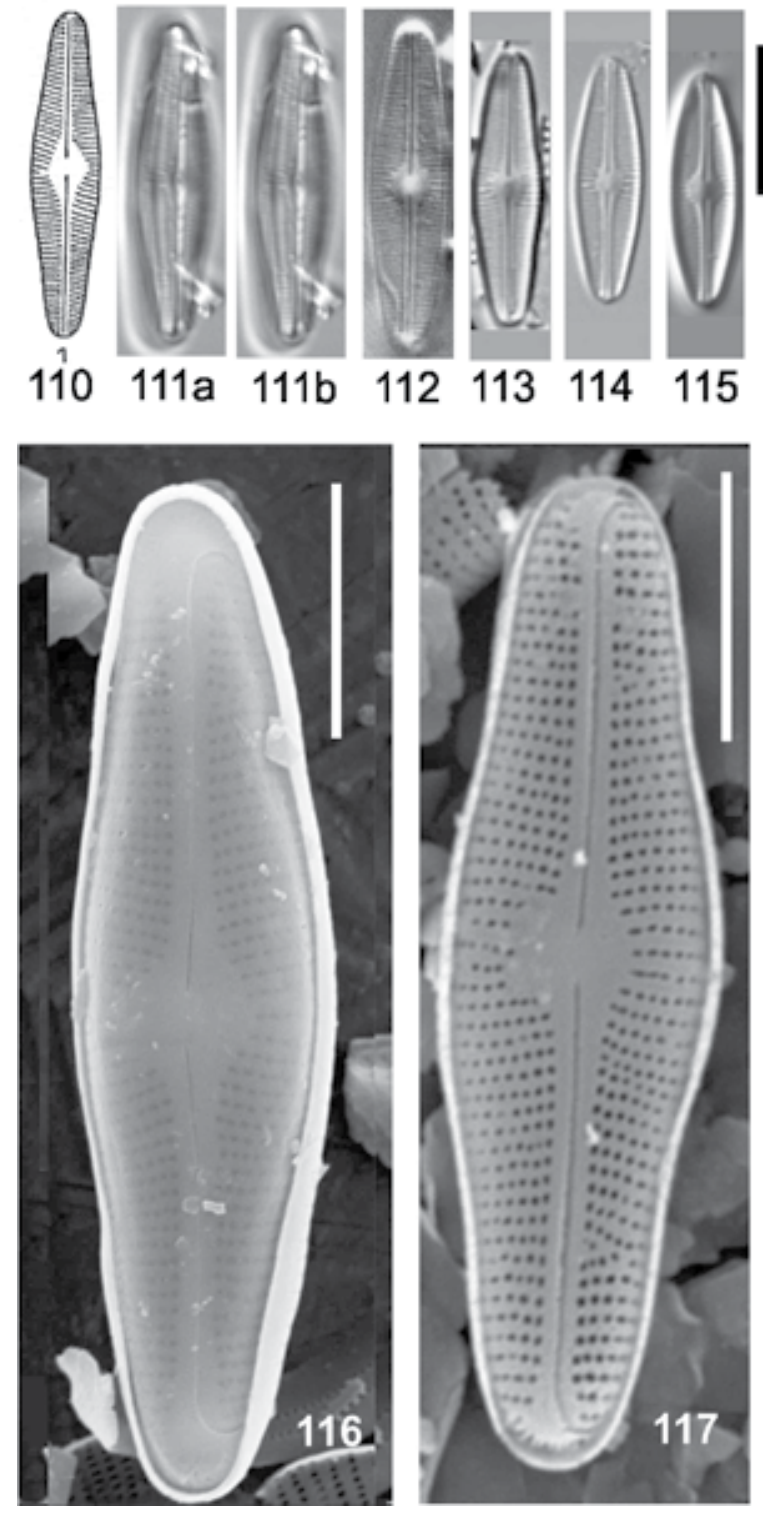

Figs 110-117. Genkalia subprocera (Hustedt) WojtaL, Ector, C.E. Wetzel, Ognjanova-Rumenova et Buczkó comb. nov.: (110) original drawing of Navicula subprocera after HustedT 1945; (111a-b) frustule at two different focuses, holotype slide, Hustedt Collection, Bremerhaven; (112-115) Genkalia subprocera from fen in the Bijambare area and Lake Câlescu; $(116,117)$ G. subprocera from Lake Calescu, SEM external view. Scale bars $10 \mu \mathrm{m}(110-115)$, $5 \mu \mathrm{m}(116,117)$.

one specimen was known from the type material. The dimensions provided by HustedT in 1945 overlap with the length and width attributed to $G$. digitulus by him (as Navicula digitulus) (Table 2). Probably the same specimen was documented by SimONSEN (1987, plate 508, figs 28,29 ) and then showed by Krammer \& Lange-Bertalot (1986, plate 77, fig. 25). No other specimen was found in the type material to our knowledge and the main morphological characters are known from Hustedt's drawing, as the only specimen lies in oblique position (Fig. 111a, b). The uncertainty around the identity of $G$. subprocera (as $N$. subprocera) was enhanced later in HustedT (1961-1966: 252, fig. 1378), where a description of $N$. digitulus was illustrated by six drawings of which five show specimens having lanceolate, gradually tapered valves with rounded apices and a large, round central area.

Genkalia subprocera co-occurred with G. digitulus in Bijambare fen area. The range of morphological variability of $G$. digitulus partly overlaps valve morphology of G. subprocera. However, they can be distinguished by outline of central area and ornamentation of the mantle near apices. Genkalia subprocera has a large and asymmetric central area with irregularly shortened striae - alternating long and short. Moreover, G. digitulus has on the mantle striae composed of one areola per stria, whereas the striae of G. subprocera are composed of at least two striae.

\section{Discussion}

Genkalia digitulus differs from most genus members by sometimes having short protracted apices and near parallel sides in the mid-valve portion, whereas, the rest possesses valves with obtusely or broadly rounded apices.

The near parallel sides observed in some populations (Figs 19-21) are at first sight similar to Adlafia species, but the valves differ in organization of the striae (Genkalia - radial becoming to parallel; Adlafia - radial becoming abruptly to divergent towards apices). Adlafia taxa have a narrow girdle, each theca consists of two copulae with a biseriate row of areolae (LANGe-Bertalot 2001). Comparing habitats of Genkalia and Adlafia species, the $\mathrm{pH}$ and ionic tolerance ranges of Genkalia are narrower. Moreover, a large part of the known records of Genkalia digitulus (as Navicula digitulus) are from lakes, whereas species of the genus Adlafia are usually aerophilous diatoms, which can be washed into a lake from surrounding area.

The similarities in morphology between Genkalia taxa and Boreozonacola LANGE-BERT., KuLIKovskiY et WitKowski in KuLIKovskiY et al. (2010) taxa are also quite remarkable and should be taken into consideration.

According to KulikovskiY et al. (2012), these genera differ in the position of hymenes "lying in a middle between external and internal apertures of areola" or not. In fact very little information on the position of the hymen in Boreozonacola is available. Images of the external and internal valve of Navicula(dicta) pseudosilicula HustedT are only provided by Lange-Bertalot \& GenKal (1999, pl. 23, figs 1,2$)$ and solely an external view was published by KuLIKovskiY et al. (2010).

The observed increase in abundance of Genkalia digitulus during periods of large inorganic, allochtonous inputs into lakes (LotTer \& HöLzer 
1994; Bigler \& HALl 2003) raises a question about the preference of this species for unstable habitat conditions.

Genkalia subprocera was described in 1945 from calcium-rich water in Buna spring. However, the description was based probably on one specimen (HustedT 1945). Unfortunately within the time the only one frustule in the slide designated by HuSTEDT has probably changed its location being at present in oblique position. But it cannot be excluded that the original HustedT drawing (1945, plate XLI, fig. 1) was his interpretation of a specimen lying in oblique position. This species was then neglected in the later elaborations (e.g. HustedT 1961-1966; KRAMMER \& LANGE-BERTALOT 1986). It remains uncertain if HusTEDT omitted Navicula subprocera due to its rarity or range of the recognized morphological variability or any other reason but the species was not synonimized with $N$. digitulus by HustedT (1961-1966) nor KRAMMER \& LANGe-Bertalot (1986).

Buna spring water is calcium rich and of high mineral content. The localities where Genkalia subprocera was found characterize water $\mathrm{pH}$ from 6.2 to 6.8 in mountain fen (KAPETANOvić et al. 2011) and 8.1 in Lake Câlcescu. Genkalia digitulus and $G$. subprocera have similar valves dimensions, partly overlapping, but they differ in size and shape of central area and striae organization in the middle valve portion (Figs 2-35, 112-115) and on the mantle near apices.

The most common species in this study from high mountain lakes seems to be G. boreoalpina. In the Schwarzsee type material of $G$. digitulus and in the sample from Retezat Mountains typical specimens of $G$. digitulus co-occurred with sparse specimens of $G$. boreoalpina. The valves morphology of $G$. digitulus clearly differs from $G$. boreoalpina in light microscope (Figs 2-35 vs. 49-92). A similar morphologically species is G. digituloides (Table 2), known from Finland and reported from the Balkans (LotTer \& Hofman 2003), Scandinavia (Wilander 2003), Carpathian high altitude lakes (BUCZKÓ et al. 2013a, b), Canadian Arctic (Bouchard et al. 2004), and Siberia (Genkal et al. 2012). Despite the fact that Genkalia digitulus (as Navicula digitulus) is the most cited species in the genus Genkalia but in fact $G$. digituloides or $G$. boreoalpina are probably more common. The co-existence of Genkalia digitulus with $G$. boreoalpina or $G$. digituloides suggests similar autecology for these diatoms.

High abundances of Genkalia digitulus and $G$. boreoalpina indicate slightly acidic, cold waters of a very low mineral content, though sparse, small cells of the first species were found in the Bijambare fen water of moderate mineral content. Another "mineralrich Sphagnum fen", from which the species was reported (without illustration) is located in the Western Carpathians (FrÁNKOVÁ et al. 2009).

According to the literature environmental changes and especially hydrogen potential $(\mathrm{pH})$ changes are characteristic feature for European Genkalia. According to BuczKó et al. (2013a) taxa belonging to Genkalia were observed during abrupt $\mathrm{pH}$ changes in lakes from the Retezat Mountains. According to Bigler \& Hall (2003) a large increase in abundance of Genkalia digitulus (as Navicula digitulus) coincided with the onset of rapid sedimentation rates. Genkalia digitulus was found most often in slightly acidic waters e.g. in Tatra Mountains (GĄSIOROWSKI \& SiENKIEwICZ 2010). Increase in abundance of this diatom coincided with a change of $\mathrm{pH}$ up to a range of 6-7 in Pyrenees (CATAlan et al. 2009). Additionally pH optimum for $G$. digitulus from northern Sweden lakes was determinated as 6.49 (Bigler et al. 2000) or 6.6 by Rosén et al. (2000). A narrow $\mathrm{pH}$ tolerance range for $G$. digitulus and probably also for $G$. boreoalpina allows the use of these taxa in paleoreconstructions for environment or climate change. The probable preference of Genkalia subprocera for circumneutral-alkaline water makes an exception among Genkalia species.

Published illustrations may suggest that morphological variability and diversity of the genus Genkalia is much larger, including northern Europe (e.g. Metzeltin \& WitKowski 1996), Africa (CocQuyT 2007), Australia (Chessman et al. 2007) and South America (SERVANT-VILDARY 1986).

ACKNOWLedGements

We would like to express our gratitude for all the valuable and constructive comments we have received from the anonymous reviewer for his comments and suggestions. We would also like to thank the Editor - Aloisie Poulíčková for her improvements and important comments. The manuscript was prepared with the help of bilateral agreements between the Hungarian and Bulgarian, and Polish and Hungarian Academies of Sciences. We also thank the Rila Mountains National Park and Tatra Mountains National Park for the permission for the study and the Hungarian Scientific Foundation no 83999, Synthesys project HU-TAF-4229. Project FP 6 (Structuring the European Research Area Programme, http://www.synthesys. info/), Natural History Museum, Budapest, Hungary.

\section{REFERENCES}

Bigler, C. \& Hall, R.I. (2002): Diatoms as indicators of climatic and limnological change in Swedish Lapland: a 100-lake calibration set and its validation for paleoecological reconstructions. - Journal of Paleolimnology 27: 97-115.

Bigler, C. \& Hall, R.I. (2003): Diatoms as quantitative indicators of July temperature: a validation attempt at century-scale with meteorological data from northern Sweden. - Palaeogeography, Palaeoclimatology, Palaeoecology 189: 147-160.

Bigler, C.; Hall, R.I. \& Renberg, I. (2000): A diatomtraining set for palaeoclimatic inferences from lakes in northern Sweden. - Verhandlungen des Internationalen Verein Limnologie 27: 1-9.

Bouchard, G.; Gajewski, K. \& Hamilton, P.B. (2004): Freshwater diatom biogeography in the Canadian 
Arctic Archipelago. - Journal of Biogeography 31: 1955-1973.

Buczkó, K.; Magyari, E.K.; Soróczki-Pintér, É.; Hubay, K.; Braun, M. \& BÁlint, M. (2009): Diatom-based evidence for abrupt climate changes during the Late Glacial in the South Carpathian Mountains. - Central European Geology 52: 249-268.

Buczkó, K.; Magyari, E.K.; Braun, M. \& Bálint, M. (2013a): Diatom-inferred lateglacial and Holocene climatic variability in the South Carpathian Mountains (Romania). - Quaternary International 293: 123-135.

Buczkó, K.; Wojtal, A.Z. \& Magyari, E. (2013b): Lectotypification, emended description and distribution of Planothidium distinctum (Achnanthidiaceae, Bacillariophyceae). - Phytotaxa 117: $1-10$.

Catalan, J.; Pla, S.; García, J. \& Camarero, L. (2009): Climate and $\mathrm{CO}_{2}$ saturation in an alpine lake throughout the Holocene. - Limnology \& Oceanography 54: 2542-2552.

Chessman, B.C; Bate, N.; Gell, P.A. \& Newall, P. (2007): A diatom species index for bioassessment of Australian rivers. - Marine and Freshwater Research 58: 542557.

Cocquyt, C. (2007): Diatom diversity in Hausburg Tarn, a glacial lake on Mount Kenya, East Africa. - Diatom Research 22: 255-285.

Fallu, M.-A.; Allaire, N. \& Pienitz, R. (2000): Freshwater Diatoms from northern Quebec and Labrador (Canada). Species-environment relationships in lakes of boreal forest, forest-tundra and tundra regions. Bibliotheca Diatomlogica 45: 1-200.

Fránková, M.; Bojková, J.; Poulíč́ová, A. \& Hájek, M. (2009): The structure and species richness of the diatom assemblages of the Western Carpathian spring fens along the gradient of mineral richness. - Fottea 9: $355-368$.

GĄSIOROWSKI, M. \& SienKIEwICZ, E. (2010): 20th century acidification and warming as recorded in two alpine lakes in the Tatra Mountains (South Poland, Europe). - Science of the Total Environment 408: 1091-1101.

GENKAL, S.I. \& KHARITONOV, W.G. (2010): Interesting findings of diatoms of the genus Naviculadicta in the lake Elgygytgyn (Chukotka). - Novitates Systematicae 44: $22-27$

Genkal, S.I.; SchUR, L.A. \& Yarushina, M.I. (2012): Diatom algae from some water bodies of Northeastern West Siberia: Communication 2. Pennatophyceae. Contemporary Problems of Ecology 5: 263-274.

Güttinger, W. (1999): Diatoms on CD-rom. Vol. 2 Navicula. - W. Guttinger, CH- 6984 Pura.

Hustedt, F. (1943): Die Diatomeenflora einiger Hochgebirgsseen der Landschaft Davos in Schweizer Alpen. - Internationale Revue der gesamten Hydrobiologie und Hydrographie 43: 124-197.

Hustedt, F. (1945): Diatomeen aus Seen und Quellgebieten der Balkan-Halbinsel. - Archiv für Hydrobiologie 40: 867-973, 12 pls 867-973.

Hustedt, F. (1961-1966): Die Kieselalgen. - In: RABENHORST, L. (ed.): Kryptogamen-Flora von Deutschland, Österreich und der Schweiz, Band VII (3, Lief. 2) von Dr. Friedrich Hustedt, Bremen, Reprint 1977. - pp. 161-348, Otto Koeltz Science Publishers, Koenigstein/West Germany.
JugGins, S. (2001): The European Diatom Database. User Guide. - Available from: http.craticula.ncl.ac.uk/ Eddi/jsp (accessed 24 January 2013).

Kapetanović, T.; JAHN, R.; RedŃí́, S. \& CARić. M. (2011): Diatoms in a poor fen of Bijambare protected landscape, Bosnia \& Herzegovina. - Nova Hedwigia 93: $125-151$.

Kawecka, B. \& Galas, J. (2003): Diversity of epilithic diatoms in high mountain lakes under the stress of acidification (Tatra Mountains, Poland). - Annales de Limnologie / International Journal of Limnology 39: 239-253.

Krammer, K. \& Lange-Bertalot, H. (1986): Bacillariophyceae. 1. Teil: Naviculaceae. - In: Ettl, H.; Gärtner, G.; Gerloff, J.; Heynig, H. \& Mollenhauer, D. (eds): Süsswasserflora von Mitteleuropa 2/1. - 876 pp., Gustav Fischer Verlag, Stuttgart, Jena.

Krstić, S.; Zech, W.; Obreht, I.; Svirčev, Z. \& Markovic, S.B. (2012): Late Quaternary environmental changes in Helambu Himal, Central Nepal, recorded in the diatom flora assemblage composition and geochemistry of Lake Panch Pokhari. - Journal of Paleolimnology 47: 113-124.

Kulikovskiy, M.S.; Lange-Bertalot, H.; Metzeltin, D. \& Witkowski, A. (2012): Lake Baikal: Hotspot of endemic diatoms I. - In: LANGE-Bertalot, H. (ed.): Iconographia Diatomologica, 23. - pp. 7-607, Koeltz Scientific Books. Koenigstein.

Kulikovikiy, M.S.; Lange-Bertalot, H.; Witkowski, A.; Dorofeyuk, N.I. \& Genkal. S.I. (2010): Diatom assemblages from Sphagnum bogs of the world. I. Nur bog in northern Mongolia. - In: LANGE-BerTALOT, H. \& Kociolek, P. (eds): Bibliotheca Diatomologica, 55. - 326 pp., J. Cramer Gebrüder Borntraeger, Stuttgart.

Lange-Bertalot, H. (2001): Diatoms of the European inland waters and comparable habitats. Navicula sensu stricto, 10 genera separated from Navicula sensu lato, Frustulia. - In: Lange-Bertalot, H. (ed.): Diatoms of Europe, Vol. 2. - 526 pp., A. R. G. Gantner Verlag K. G., Vaduz.

Lange-Bertalot, H. \& Genkal, D. (1999): Diatoms from Siberia I. Islands in the Arctic Ocean (Yugorsky-Shar Strait) - In: LANGE-BERTALOT, H. (ed.): Iconographia Diatomologica. Annotated Diatom Micrographs, Vol. 6. - 271 pp., Koeltz Scientific Books, Koenigstein ( $2^{\text {nd }}$ corrected printing).

Lange-Bertalot, H. \& Metzeltin, D. (1996): OligotrophieIndikatoren. 800 Taxa in drei ökologisch diversen Seen-Typen. - In: Lange-Bertalot, H. (ed.): Iconographia Diatomologica. Annotated Diatom Micrographs, Vol. 2. - 390 pp., Koeltz Scientific Books, Koenigstein.

Larsen, J.; Jones, V.J. \& EIDE, W. (2006): Climatically driven $\mathrm{pH}$ changes in two Norwegian alpine lakes. - Journal of Paleolimnology 36: 175-187.

Lotter, A.F. \& Hofmann, G. (2003): The development of the late-glacial and Holocene diatom flora in Lake Sedmo Rilsko (Rila Mountains, Bulgaria). - In: Tonkov, S. (ed.): Aspects of Palynology and Palaeoecology. Festschrift in honour of Elissaveta Bozilova. - pp. 171-183, Pensoft Publishers, Sofia.

Lotter, A.F. \& Hölzer, A. (1994): A high-resolution lateglacial and early Holocene environmental history 
of Rotmeer, Southern Black Forest (Germany). In: Lotter, A.F. \& AmmanN, B. (eds): Festschrift Gerhard Lang, Dissertationes botanicae, Vol. 234. pp. 365-388, J Cramer, Berlin.

MARCINIAK, B. \& CieŚLA, A. (1983): Badania diatomologiczne i geochemiczne późnoglacjalnych i holoceńskich osadów z Przedniego Stawu w Dolinie Pięciu Stawów Polskich (Tatry) - Diatomological and geochemical studies on Late Glacial and Holocene sediments from the Przedni Staw Lake in the Dolina Piêciu Stawów Polskich Valley (Tatra Mts). - Kwartalnik Geologiczny 27: 123-150.

Metzeltin, D. \& Witkowski, A. (1996): Diatomeen der Bären-Insel. Süsswasser- und marine Arten. - In: Lange-Bertalot, H. (ed.): Iconographia Diatomologica. Annotated Diatom Micrographs. 4. Taxonomy. - pp. 3-232, Koeltz Scientific Books, Königstein.

Ognjanova-Rumenova, N.; Botev, I. \& Kernan, M. (2009): Benthic diatom flora in relation to chemical and physical factors in high mountain lakes in the Rila Mountains (southwestern Bulgaria). - Advances in Limnology 62: 145-158.

Ognjanova-Rumenova, N.; Botev, I.S. \& Vidinova, Y.N. (2011): Using sediment diatom assemblages in the assessment of environmental changes in high- altitude lakes, Rila Mts, Bulgaria. - Phytologia Balcanica 17: 173-184.

Reichardt, E. (1985): Diatomeen an feuchten Felsen des Südlichen Frankenjuras. - Berichte der Bayerischen Botanischen Gesellschaft 56: 167-187.

Rosén, P.; Hall, R.; Korsma, T. \& Renberg, I. (2000): Diatom transfer-functions for quantifying past air temperature, $\mathrm{pH}$ and total organic carbon concentration from lakes in northern Sweden. Journal of Paleolimnology 24: 109-123.

Sabater, S. \& RocA, J.R. (1992): Ecological and biogeographical aspects of diatom distribution in Pyrenean springs. - British Phycological Journal 27: 203-213.

SERVANT-VILDARY, S. (1986): Les diatomées actuelles des Andes de Bolivie (Taxonomie, écologie). - Cahiers de Micropaléontologie 1: 99-124.

SimONSEN, R. (1987): Atlas and catalogue of the diatom types of Friedrich Hustedt. - Vol. 1, Calatogue, 525 pp.; Vol. 2, Atlas, pls 1-395, 597 pp.; Vol. 3, Atlas, pls 396-772, 619 pp., J. Cramer, Berlin-Stuttgart..

ŠTeFKovÁ, E. (2006): Epilithic diatoms of mountain lakes of the Tatra Mountains (Slovakia). - Biologia, Bratislava 61/Suppl. 18: 101-108.

WiLANDER, A. (ed.) (2003): Skyddad natur. En undersökning av två sjöar och deras utloppsbäckar i Padjelanta 2002. - 76 pp., Institutionen för miljöanalys, SLU, Box 705075007 Uppsala.

(C) Czech Phycological Society (2014)

Received April 16, 2014

Accepted July 8, 2014 